\title{
Research Paper Components of household income and elasticity of consumption expenditure in Kurnool and Prakasam districts of Andhra Pradesh
}

\author{
K. Suhasini, G.P. Sunandini, I. Shakuntala Devi and Tewodros Tefera
}

ABSTRACT : This paper explores the nature of the different income sources, consumption expenditure and income elasticity of different group of items and the relationship among them as exhibited in the study areas. Both households sources of income and consumption expenditure shows similar trend in the two districts. From the two models used: total consumption expenditure and family size elasticities of consumption expenditure and income and family size elasticities of consumption expenditure, the former provide accurate prediction of Engel laws of consumption for classification consumption goods into inferior, normal and luxuries goods. It was found that increase in family size has an adverse effect in consumption of most luxuries and normal goods. It was noted that normal and inferior goods become luxury goods as family size increases. It implies that increase in the family size affects standard of living and quality of life adversely. Hence, appropriate strategies should be put in place to curb the negative impacts of population explosion to hasten the nation move towards prosperity.

KEY WORDS : Household sources of income, Consumption expenditure, Elasticity of expenditure, Income

How To Cite This PAPer: Suhasini, K., Sunandini, G.P., Shakuntala Devi, I. and Tefera, Tewodros (2020). Components of household income and elasticity of consumption expenditure in Kurnool and Prakasam districts of Andhra Pradesh. Internat. Res. J. Agric. Eco. \& Stat., 11 (2) : 269-277, DOI : 10.15740/HAS/IRJAES/11.2/ 269-277. Copyright@2020:Hind Agri-Horticultural Society. 